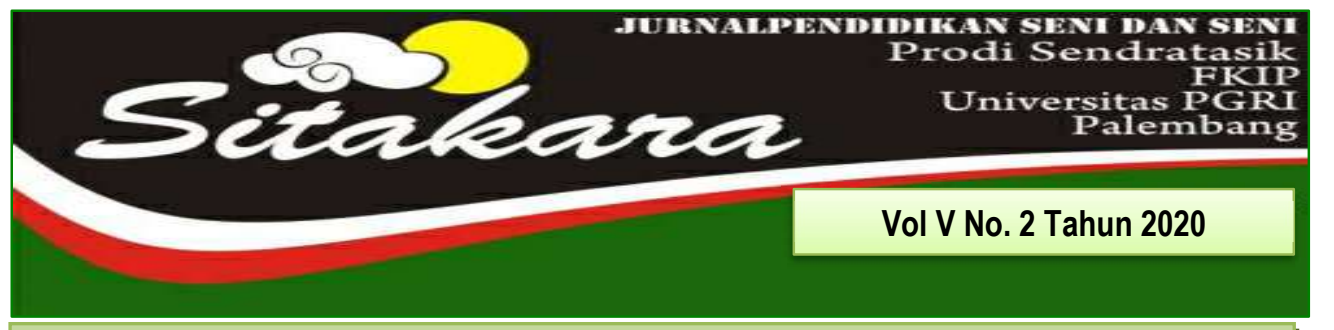

FUNGSI DAN MAKNA BHAJAN PADA UPACARA AGAMA HINDU DI KUIL SHRI MARIAMMAN KOTA MEDAN

(Agung Suharyanto, dkk)

KESENIAN SRANDUL DALAM UPACARA BERSIH DESA BULU KALURAHAN KARANGMOJO KECAMATAN KARANGMOJO KABUPATEN GUNUNGKIDUL YOGYAKARTA

(Supriyanto)

FUNGSI DAN MAKNA LAGU GUBANG DALAM UPACARA SIAR MAMBANG PADA MASYARAKAT TANJUNGBALAI

(Theo henry tua siagian ${ }^{1}$, pulumun p. Ginting ${ }^{2} \&$ wiflihani)

FUNGSI TARI MAPAK ADAT MUARA KUANG SEBAGAI TARI SAMBUT

(Nadia Rahma Aprilia', Dessy Wardiah², Treny Hera ${ }^{3}$ )

MAKNA SIMBOLIK RAGAM HIAS PADA RUMAH LIMAS PALEMBANG

(Ferri Hidayad ${ }^{1}$ Decky Kunian ${ }^{2}$ )

GAYA MUSIK SAHILIN DALAM KESENIAN MUSIK BATANGHARI SEMBILAN DI KOTA PALEMBANG

(Feri Firmansyah)

TRANSPOSISI TTI (TRANSFER, TRANSLATION, IMITATE) DALAM PEMBELAJARAN NOTASI MUSIK MELALUI SCORE CREATOR

(A Heryanto ${ }^{1}$ Dedy Firmansyah ${ }^{2}$ )

RASE TAK SERUPE MUSIK MELAYU TRADISI DENGAN PENGEMBANGAN MUSIK MODERN DALAM RUANG PERTUNJUKAN KOMPOSISI MUSIK NUSANTARA (Rio Eka Putra)

BENTUK SYAIR LAGU DALAM PERTUNJUKAN SYAROFAL ANAM DI PEDESTRIAN S UDIRMAN KOTA PALEMBANG

(Nofroza Yelli ${ }^{1}$ Deria Sepdwiko² ${ }^{2}$

"Betenun" Sebuah Wujud Proses Kreatif Mahasiswa Seni Pertunjukan Universitas PGRI PALEMBANG

(Nurdin $^{1}$ Naomi Diah Budi Setyaningrum ${ }^{2}$ ) 
DAFTAR ISI

FUNGSI DAN MAKNA BHAJAN PADA UPACARA AGAMA HINDU DI KUIL 1-15 SHRI MARIAMMAN KOTA MEDAN

(Agung Suharyanto, dkk)

KESENIAN SRANDUL DALAM UPACARA BERSIH DESA BULU KALURAHAN

$16-26$

KARANGMOJO KECAMATAN KARANGMOJO KABUPATEN GUNUNGKIDUL YOGYAKARTA

(Supriyanto)

FUNGSI DAN MAKNA LAGU GUBANG DALAM UPACARA SIAR MAMBANG 27-39 PADA MASYARAKAT TANJUNGBALAI

(Theo henry tua siagian ${ }^{1}$, pulumun $p$. Ginting ${ }^{2} \&$ wiflihani)

FUNGSI TARI MAPAK ADAT MUARA KUANG SEBAGAI TARI SAMBUT

40-52

(Nadia Rahma Aprilia', Dessy Wardiah², Treny Hera')

MAKNA SIMBOLIK RAGAM HIAS PADA RUMAH LIMAS PALEMBANG

53-61

(Ferri Hidayad ${ }^{1}$ Decky Kunian ${ }^{2}$ )

GAYA MUSIK SAHILIN DALAM KESENIAN MUSIK BATANGHARI SEMBILAN DI $\quad 62-76$ KOTA PALEMBANG

(Feri Firmansyah)

TRANSPOSISI TTI (TRANSFER, TRANSLATION, IMITATE) DALAM 77-85 PEMBELAJARAN NOTASI MUSIK MELALUI SCORE CREATOR (A Heryanto ${ }^{1}$ Dedy Firmansyah ${ }^{2}$ )

RASE TAK SERUPE MUSIK MELAYU TRADISI DENGAN PENGEMBANGAN MUSIK MODERN DALAM RUANG PERTUNJUKAN KOMPOSISI MUSIK NUSANTARA

(Rio Eka Putra)

BENTUK SYAIR LAGU DALAM PERTUNJUKAN SYAROFAL ANAM DI PEDESTRIAN SUDIRMAN KOTA PALEMBANG

(Nofroza Yelli ${ }^{1}$ Deria Sepdwiko ${ }^{2}$ )

"BETENUN" SEBUAH WUJUD PROSES KREATIF MAHASISWA SENI

$109-120$ PERTUNJUKAN UNIVERSITAS PGRI PALEMBANG

(Nurdin ${ }^{1}$ Naomi Diah Budi Setyaningrum ${ }^{2}$ )

86-95 


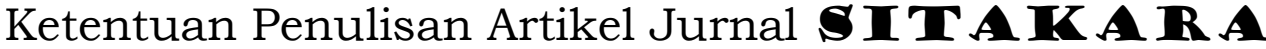

1. Naskah berbahasa Indonesia bertemakan Seni Budaya yang meliputi hasil penelitian pengajaran seni budaya, cabang seni, dan kebudayaan.

2. Naskah harus asli dan belum pernah dimuat dalam media lain. Naskah dapat berupa hasil penelitian perorangan atau kelompok.

3. Naskah ditulis dengan cara-cara yang sesuai dengan ketentuan penulisan artikel ilmiah menggunakan bahasa Indonesia yang baku, berupa ketikan, beserta soft line dalam CD-RW atau dengan mengirimkan email pada redaksi Jurnal SITAKA RA dengan alamat email: jurnalsitakarasendratasik@yahoo.com, spasi 1,5 jenis huruf Arrial Narrow ukuran 12, dengan panjang naskah antara 8-15 halaman pada kertas A4.

4. Artikel hasil penelitian memuat:

JUDUL

Nama Penulis

Abstrak

A. PENDAhuluan

B. METODE PENELITIAN

C. HASIL DAN PEMBAHASAN

D. SIMPULAN

5. Artikel kajian konseptual memuat:

JUDUL

Nama Penulis

Abstrak

PENDAHULUAN
: XXX (HURUF KAPITAL)

: (disertai jabatan dan institusi)

: (Bahasa Indonesia yang memuat 100150 kata diikuti kata kunci, dengan jenis huruf Arrial Narrow dan ukuran huruf 11 spasi tunggal serta dicetak miring)

: (Memuat latar belakang masalah, tinjauan pustaka secara ringkas, masalah penelitian dan tujuan penelitian)

: (Berisi simpulan)

\section{: XXX (HURUF KAPITAL)}

: (disertai jabatan dan institusi)

: (Bahasa Indonesia yang memuat 100150 kata diikuti kata kunci, dengan jenis huruf Arrial Narrow dan ukuran huruf 11 serta dicetak miring)

: (Memuat latar belakang masalah, tinjauan pustaka secara ringkas, 
Sub Judul

Sub Judul

SIMPULAN

DAFTAR PUSTAKA masalah penelitian dan tujuan

penelitian)

: Sesuai dengan kebutuhan (tanpa

numbering)

: (Berisi simpulan dan saran)

: (Berisi pustaka yang dirujuk dalam uraian naskah

6. Referensi sumber dalam teks artikel ditulis dengan menggunakan side note, contoh: (Jalalluddin, 1991:79); (Taufik, 2005;350); (Hamid dan Madjid, 2011:43). Sementara penulisan daftar pustaka disusun dengan ketentuan. Nama Pengarang. Tahun Terbit. Judul (dicetak miring). Kota Terbit: Nama Penerbit. Contoh: Koentjaraningrat. 2010. Manusia dan Kebudayaan Di Indonesia. Jakarta: Djambatan.

Daftar pustaka hanya memuat pustaka/sumber yang dirujuk dalam uraian dan disusun menurut abjad, tanpa nomor urut.

7. Naskah yang dimuat akan disunting kembali oleh redaksi tanpa mengubah isinya.

8. Naskah yang ditolak (tidak bisa dimuat) akan dikirim kembali ke penulis dengan pemberitahuan tertulis dari redaksi atau alamat email.

9. Penulis yang naskahnya dimuat akan mendapatkan 1 (satu) majalah nomor yang bersangkutan.

10. Contact Person: Treny Hera (085357344704) dan Mainur (081373165553). 


\title{
FUNGSI DAN MAKNA BHAJAN PADA UPACARA AGAMA HINDU DI KUIL SHRI MARIAMMAN KOTA MEDAN
}

\author{
Oleh: OK. Dedy Arwansyah4), Satrina Titania Siahaan ${ }^{4)}$, Rentha Bitha Eunike4) \& Tedi Tri Wibowo4) \\ Agung Suharyanto1)*, Onggal Sihite 2), Wiflihani3), Citra Girsang4), Firza Ramadhan4),
1) Fakultas IImu Sosial dan IImu Politik Universitas Medan Area, Indonesia
2) Fakultas Bahasa dan Seni, Universitas Negeri Medan, Indonesia
3) Fakultas Bahasa dan Seni, Universitas Negeri Medan, Indonesia
4) Fakultas IImu Sosial, Universitas Negeri Medan, Indonesia \\ Email: agungsuharyanto@staff.uma.ac.id
}

\begin{abstract}
Abstrak
Musik memiliki makna dalam pelaksanaan ibadah Agama Hindu dikarenakan musik adalah simbol pemujian terhadap Sang Yhang Whidi (Tuhan Pencipta Alam semesta). Shri Mariamman adalah Kuil yang berlokasi di Kota Medan. Bhajan Muruga merupakan lagu (mantra) renungan guna memuja dewa-dewi mereka ketika melakukan ibadah. Artikel ini bertujuan untuk mengetahui fungsi dan makna musik pada pelaksanaan ibadah Agama Hindu di Kuil Shri Mariamman, Medan, Sumatera Utara. Metode penelitian deskriptif yang bersifat kualitatif digunakan sebagai cara untuk menjelaskan hasil penelitian. Teknik pengumpulan data pada penelitian ini yaitu melalui observasi, wawancara, dan dokumentasi. Instrumen penelitian ini menetapkan informan yang terlibat maupun yang tidak terlibat secara langsung. Hasil penelitian ini didapatkan bahwa peran musik dalam ibadah umat agama Hindu sebagai sarana beribadah kepada Sang Yhang Whidi, Musik dijadikan sebagai bentuk pengiring nyanyian yang disebut dengan mantra sebagai doa-doa pemujaan. Makna yang terkandung di dalamnya adalah Nyanyian yang diringi dengan musik menandakan pemujaan yang tulus, sungguh sungguh, penambah semangat, memuja, penyampaian doa dan rasa syukur umat Hindu kepada Sang Yhang Whidi.
\end{abstract}

Kata kunci: Fungsi, makna, musik, ibadah, Shri Mariamman.

\section{A. PENDAHULUAN}

Musik merupakan salah satu bentuk kesenian yang dikenal oleh masyarakat pada umumnya selain seni tari, rupa, dan drama. Musik sebagai seni memiliki tujuan, di mana ini dikelompokkan oleh (Soedarsono, 1999) menjadi tiga, yakni: (1) seni untuk tujuan ritual, (2) seni untuk tujuan presentasi estetis, dan (3) seni sebagai hiburan. Selain itu, musik sebagai bagian dari kesenian secara langsung menjadi bagian pula dari unsur-unsur kebudayaan. Hal ini didasarkan atas pernyataan Koentjaraningrat (1985) yang membagi kebudayaan menjadi tujuh unsur (cultural universals). Wiflihani (2016) mengatakan "setiap karya seni musik tentunya mengandung pesan yang ingin 
disampaikan kepada penghayat. Pesan itu berupa nilai-nilai luhur dan mulia yang sangat berguna bagi perkembangan jiwa manusia".

Selanjutnya, Ali (dalam Wiflihani, 2016) mengatakan musik di beberapa daerah Indonesia kebanyakan memiliki fungsi yang berkaitan dengan upacara kematian, perkawinan, kelahiran, dan keagamaan. Selain itu bunyi-bunyi yang dihasilkan oleh alat music tertentu juga diyakini memiliki kekuatan magis (Wiflihani, 2018). Maka dari itu, ada beberapa instrument music yang digunakan sebagai sarana kegiatan upacara atau kegiatan agama masyarakat. Salah satu agama yang menjadikan musik untuk mengiringi setiap aktivitas keagamaan ialah agama Hindu. Hal ini terkait dengan bagaimana seni dalam menciptakan ruang-ruang sakral serta menyatu dengan prosesi ritual yang sakral tersebut.

Salah satu kuil Hindu yang menjadi tempat ibadah bagi umatnya dan sangat terkenal di Medan adalah Kuil Shri Mariamman. Bangunannya telerletak di Jalan Teuku Umar No. 8, Kelurahan Petisah Tengah, Medan. Kuil ini dibangun tahun 1884 oleh masyarakat Tamil Hindu di Medan. Dari segi arsitektur, kuil ini telah mengalami perombakan secara total dari bangunan lama ke bangunan baru. Pada tanggal 23 Oktober 1991 bangunan yang baru ini diresmikan oleh Gubernur Sumatera Utara, yang pada saat itu adalah Raja Inal Siregar (Sinar, 2008).

Berdasarkan maknanya, Shri Mariamman adaah nama lain untuk Dewi Parwethi (Sakthi Dewa Syiwa). Lingga, dalam mitologi Hindu, adalah alat kelamin pria (phallus), lambang Siwa sebagai dewa semesta, kebalikan dan yoni adalah alat kelamin perempuan sebagai Tara atau timbalan dan linggam merupakan lambang shakti atau prakrti yang dijabarkan dalam bentuk unsur kewanitaan" (Ensiklopedia Indonesia Ikhtisar Baru, Jakarta: Van Hove, 1990, 2.020 dan 3.993). Menurut keterangan narasumber, Naga Linggam, ini menunjukkan bahwa umat Hindu Tamil sangat mengagumi figur seorang ibu yang memiliki kasih sayang yang begitu agung. Demikianlah gambaran sekilas dari Bangunan Shri Mariamman Kuil memiliki ukuran luas yaitu 15 kali 10 meter tersebut.

Letak bangunan kuil ini menghadap matahari terbit. Adapun konsep matahari terbit menurut ajaran agama Hindu adalah bahwa matahari adalah sinar Tuhan yang menberikan kehidupan bagi makhluk hidup di dunia. Di bahagian halamn depan gedung, dinding 
bagian atas, atap gedung, dan bahagian dalam terdapat patung dewa-dewi agama Hindu dan patung-patung manusia.

Bagi agama Hindu, baik Hindu Tamil, Hindu Bali, Hindu Jawa, dan Hindu Karo, sumber dari agama mereka adalah Kitab Suci Weda. Weda berasal dari bahasa India yang berarti pengetahuan suci. Menurut agama Hindu, kitab suci Weda merupakan Wahyu Sang Hyang Wasa (Tuhan Yang maha Esa) kepada para Maharesi lebih dari 4.000 tahun yang Ialu (Cudamani, 1990). Kitab Suci Weda memiliki empat bahagian: (a) Rig Weda, (2) Sama Weda, (3) Yajur Weda, dan (4) Atharva Weda. Agama Hindu berintikan ajaran percaya kepada Tuhan Yang Maha Kuasa. Pemujaan kepada Tuhan diwujudkan dalam nama-nama dewa seperti: Brahma, Wisnu, Syiwa, Murugen, Ganesha, Mahadewa, Iswara, dan sebagainya menurut peranan dan fungsinya. Di dalam Kitab Suci Weda ada ratusan nama dewa yang disebutkan. Istilah dewa berasal dari akar kata dev yang berarti sinar. Jadi dewa merupakan sinar kekuatan Tuhan dan Dewa sendiri adalah Tuhan.

Shri Mariamman adalah kuil atau tempat ibadah umat Hindu yang berlokasi di kota Medan. Di tengah ibadah, musik hampir tidak pernah lepas dalam mengiringi setiap proses ibadahnya. Bhajan Muruga merupakan lagu renungan yang dinyanyikan oleh umat Hindu di Kuil Shri Mariamman guna memuja Dewa dan Dewi mereka. Lagu ini dinyanyikan setiap hari Jumat atau malam Sabtu bersama-sama di dalam kuil. Ada banyak judul lagu (biasa disebut mantra) yang dinyanyikan oleh umat Hindu tergantung pada nama dewa apa yang sedang disembah.

Berdasarkan paparan ini terlihat bahwa musik memiliki fungsi cukup beragam, salah satunya ialah untuk mengiringi ritual keagamaan/ibadah sehingga musik menjadi sangat berperan dalam agama. Analisis musik mengenai arti, makna, dan momen untuk dinyanyikan dapat ditinjau dari bentuk melodi, harmoni, tempo, dinamika, dan lirik dalam lagu. Hal ini akan membantu penyajian deskriptif mengenai makna dan peran musik dalam agama Hindu di Kuil Shri Mariamman. Pemahaman mengenai peran seni dalam suatu agama sangat perlu untuk dikaji guna mendapatkan esensi sebenarnya dari hubungan menyeluruh antara agama dan kesenian. Geertz (1973), mengungkapkan bahwa agama merupakan suatu sistem simbol bertindak untuk memantapkan perasaan-perasaan (moods) dan motivasi 
secara kuat, menyeluruh, dan bertahan lama pada diri manusia, dengan cara memformulasikan konsepsi-konsepsi mengenai suatu hukum (order) yang berlaku umum berkenaan dengan eksistensi, dan menyelimuti konsepsikonsepsi ini dengan suatu aura tertentu yang mencerminkan kenyataan, sehingga perasaan-perasaan dan motivasi-motivasi tersebut nampaknya secara tersendiri adalah nyata ada.

Penelitian terkait pujian dalam ibadah sudah pernah dilakukan sebelumnya, misalnya saja dalam penelitian Theresia (2015) dalam penelitiannya membahas mengenai upacara Nawaratri yang dilakukan dalam Agama Hindu. Upacara Nawaratri dilaksanakan untuk memperingati kemenangan dharma (kebaikan) terhadap adharma (kejahatan). Upacara ini adalah upacara untuk menghormati kemenangan Sri Rama melawan Rawana yang disebut juga Dasamukha (berkepala sepuluh). Upacara Nawaratri dilaksanakan dengan mengikuti tahap-tahap yaitu tahap pertama adalah abhisegen (penyucian arca), dan setelah itu dilakukan arathi (proses mengelilingi arca suci dengan sarana api suci dan tempat suci searah putaran jarum sebanyak tiga kali), dan alankaram (menghias arca). Penelitian relevan ini memiliki
perbedaan dan persamaan dengan
penelitian yang akan dilaksanakan. Hal
tersebut dapat dilihat dari topik yang
dibahas dalam penelitian ini yaitu sama-
sama membahas mengenai Agama Hindu. Hanya saja penelitian relevan ini membahas mengenai upacara Nawaratri sedangkan penelitian yang akan dilaksanakan ini membahas mengenai musik yang digunakan dalam ibadah Agama Hindu tersebut, selain itu musik dalam Agama Hindu ini dilihat atau dianalisis dengan menggunakan perspektif Antropologi.

Selanjutnya Pasaribu (2018), sebuah penelitian yang membahas struktur dan makna teks Bhajan, struktur musikalnya, dan tekstual dalam masyarakat Hindu Tamil di Kota Medan. Metode yang digunakan dalam penelitian ini adalah metode kualitatif dengan teknik penelitian lapangan melalui proses kerja yaitu : studi kepustakaan, observasi, wawancara, perekaman atau dokumentasi kegiatan, transkripsi dan analisis laboratorium. Mengacu pada penelitian di atas, artikel ini banyak mengambil data mengenai bhajan yang dibahas dalam makna dan fingsinya pada ibadah sembahyang umat Hindu. 
Berdasarkan uraian di atas peneliti tertarik untuk melakukan sebuah kajian mengenai bagaimana peran dan makna bhajan dalam ibadah Agama Hindu di Kuil Shri Mariamman.

\section{B. METODE PENELITIAN}

Penelitian ini menggunakan metode penelitian deskriptif dengan pendekatan kualitatif. Penelitian deskriptif merupakan salah satu metode penelitian yang sering digunakan ketika melakukan penelitian yang bersifat terjun langsung ke lokasi penelitian (lapangan).

Dalam proses penelitian yang dilakukan maka peneliti akan menghasilkan suatu gambaran mengenai fenomena yang diteliti melalui proses mengumpulkan data dari lapangan. Penelitian deskriptif pada umumnya dilakukan dengan cara observasi atau pengamatan langsung ke lapangan serta wawancara langsung dengan informan. Hal ini dilakukan untuk mendapatkan data mentah tentang fenomena yang sedang diteliti sehingga peneliti bisa menganalisisnya.

Nazir (1988) mengungkapkan ada beberapa langkah yang dapat di lakukan ketika melakukan penelitian deskriptif, yang pertama, memilih dan merumuskan masalah, adapun masalah yang ditemukan ketika melakukan penelitian ini adalah bagaimana peran musik dan makna musik bagi penganut agama Hindu di Kuil Shri Mariamman. Kedua, menentukan tujuan dari penelitian yang akan dikerjakan, adapun tujuan dari penelitian ini adalah untuk mengetahui peran dan makna musik bagi penganut agama Hindu di Kuil Shri Mariamman. Ketiga, perumusan kerangka teori atau kerangka berpikir, kerangka pemikirannya yaitu setelah dilakukan pengamatan secara langsung ke lokasi penelitian rumah ibadah agama Hindu, maka di peroleh kesimpulan bahwa penganut agama Hindu di Kuil Shri Mariamman selalu memakai musik di dalam acara ibadah yang mereka lakukan. Musik tersebut memiliki peran dan makna bagi penganut agama Hindu itu sendiri. Keempat, menelusuri sumber-sumber kepustakaan, sumber-sumber yang peneliti gunakan untuk membantu menyelesaikan laporan penelitian adalah studi pustaka terhadap literatur seperti jurnal dan bahan dari internet yang berkaitan dengan agama Hindu. Kelima, yaitu melakukan kerja lapangan untuk mengumpulkan data, pengumpulan data dilakukan melalui observasi/pengamatan langsung ke rumah ibadah agama Hindu serta melakukan 
wawancara langsung ke masyarakat Hindu menyanyikan mantra dan namapenganut agama Hindu.

nama suci Tuhan secara beramai-ramai.

Dalam memperjelas fokus penelitian, Bhajan bisa dilakukan di kuil atau tempat maka instrumen penelitian dalam penelitian khusus tertentu. Bhajan juga merupakan kualitatif harus mampu melengkapi data musik klasik India yang dimainkan dan membandingkan data yang telah berdasarkan (tempo dalam irama) dengan ditemukan di lapangan. Untuk memperoleh data dari lapangan dapat digunakan melalui wawancara, observasi lapangan maupun dokumentasi yang didukung oleh peralatanperalatan yang mendukung seperti kamera dan peralatan tulis yang dibutuhkan.

Wawancara dilakukan kepada penganut agama Hindu di Kuil Shri Mariamman untuk memperoleh informasi mengenai peran dan makna yang dirasakan oleh penganut agama Hindu. Pengumpulan data melalui studi literatur, observasi. wawancara dan dokumentasi yang berkenaan dengan pembahasan mengenai musik dalam ibadah agama Hindu dalam kuil Shri Mariamman.

\section{HASIL DAN PEMBAHASAN}

\section{Bhajan}

Bhajan berarti memuja, bersujud, bersembah, dalam perkembangan sampai kini, Bhajan berarti Kidung Suci dengan mengutamakan penggunaan nama-nama suci Tuhan (Pemajun, t.t.). Pada praktiknya dalam melakukan Bhajan, penganut agama

iringan alat musik tradisi India seperti; tabla, mridanga, sarangi venu, venna dan lain-lain. Dalam nyanyian lagu-lagu bhajan terdapat banyak kata- kata yang menggunakan nama Tuhan dan berisikan kehidupan Tuhan. Kata Bhajan berasal dari kata "Bhaj" yang berarti: memuja, menyembah, bersujud, dan terikat pada Tuhan. Bhajan diartikan sebagai kegiatan pemujaan nama-nama Tuhan dengan dinyanyikan lagu-lagu suci yang di dalamnya sarat dengan nama-nama Tuhan. Bhajan terdapat beberapa dasar dalam bernyanyi untuk mencapai kesempurnaan; Bhaavana (perasaan), Raaga (lagu/tembang), dan Thaala (irama). Bhaavana terkait dengan kegiatan mendalami pelajaran berarti satu kegiatan yang dipakai guna mencapai penguasaan materi dalam bhajan, Raaga berarti menanamkan rasa kasih terhadap hal yang telah di dalamnya, dan Thaala berarti ungkapan pengetahuan yang dimiliki seseorang secara jelas dan saling kaitmengkait (Batubara, 2012). 
Pada saat melakukan bhajan, tempat yang harus di perhatikan posisi/ tempat altar yang harus di perhatikan di dalam lokasi berdoa, karena perlu menentukan batas-batas yang menjadi ketentuan pada saat berdoa. Dalam kenyataan bhajan dilakukan untuk memuja Tuhan, maka pada saat di kuil Shri Mariamman ditetapkan beberapa patung yang dipasang di depan altar adalah patung Dewa Siva, Dewa Visnu, Dewa Ganesha, Dewi Mariamman, Dewa Muruga, untuk mendekatkan diri kepada Tuhan dan membawa arcane. Maka dari itu Rahmat Tuhan dapat diperoleh dengan menyanyikan banyak kidung-kidung suci. dengan dilakukan lagulagu yang disajikan dengan penuh perasaan, dengan nada dan irama dapat berguna untuk menyenangkan Tuhan (Lubis, 2015).

Bhajan dilakukan dengan cara; "call and response", ada beberapa lead singer yang bertindak sebagai pemimpin saat bernyanyi, ini biasanya dilakukan oleh perempuan dan laki-laki secara bergantian selama bhajan dilaksanakan. Dan kemudian para bhakta yang lain bertindak sebagai choir atau paduan suara yang mengulangi lirik yang sama dengan lead singer nyanyikan. Pada awal nyanyian bhajan iringan musik dibuat lebih sederhana dan lambat, kemudian pada beberpa pengulangan berikutnya iringan musik semakin cepat dan diikuti dengan tepuk. Lagu yang dinyanyikan pada saat melaksana bhajan ada 8 atau 12 lagu, dan semua lagu menggunakan konsep bernyanyi yang sama diawali dari lambat, lembut, cepat, dan lebih cepat (klimaks) kemudian kembali lambat dan lembut (Pasaribu, 2018).

Saat menyanyikan bhajan para bhakta diiringi instrumen yang terdiri dari sebuah, tamborin dan cincingan dan sepasang tabla. Pad saat bernyanyi, iringan musik turut berperan dalam mencapai penyaluran pujian Tuhan atau Guru Sad Bhagawan, karena saat bernyanyi musik ikut mengambil peran untuk mengantarkan para bhakta pada sikap klimaks dalam pada menyampaikan pujian dan doa kepada Tuhan dan mengantarkannya kembali pada suasana yang lebih tenang dan rileks. Bhakta yang hadir bernyanyi dengan sepenuh hati, saat bernyanyi, meletakkan kedua tangan di depan dada dan menutup mata dengan sikap menyembah, dan menikmati setiap nyanyian bhajan yang dilaksanakan. Sebagian dari mereka bernyanyi sambil meletakkan tangan ke atas dengan posisi yang dengan tangan menyembah sambil 
bernyayi dan menutup mata (Pasaribu, 2018).

Urutan dalam menyanyikan lagu-lagu bhajan, diawali oleh pemujaan terhadap Ganesha, setelah itu tidak ada aturan untuk menentukan puja yang mana yang harus dikidungkan. Biasanya sesuai tradisi dilanjutkan dengan Guru, Dewi, Shiva, Krisna, Rama, Visnhu, Muruga, sesuai dengan buku "Bhajan 2015".

Fungsi Musik Pada Pelaksanaan Ibadah

Perayaan ibadah di kuil Shri Mariamman kota Medan dilakukan pada hari Jumat malam. Pada saat peneliti melakukan observasi langsung dengan mengikuti tata ibadah, peneliti melihat dan menyasikan secara langsung musik serta nyanyian-nyanyian persembahan yang dilantunkan oleh umat Hindu sebagai pemujaan dan penghormatan kepada Tuhan dan dewa-dewa.

Musik bagi perayaan ibadah umat Hindu sangatlah penting. Musik merupakan salah satu bagian dalam tatanan ibadah umat Hindu dikarenakan musik adalah simbol pemujian terhadap Sang Yhang Whidi.

Sang Yhang Whidi merupakan Tuhan yang maha kuasa sebagai pencipta dan pemelihara seluruh alam semesta yang memiliki banyak sifat tetapi menjadi satu yang disebut dengan Trimurti. Umat Hindu menyanyikan kidung kidung pujian sebagai rasa hormat dan kekaguman terhadap pencipta alam semesta disertai dengan lantunan alat musik seperti gendang dan tamborin. Pada agama Hindu, budaya dan kesenian merupakan satu kesatuan yang tidak bisa di pisahkan dalam hidup keagamaan. Kesenian dan budaya merupakan penambah kesakralan dan kehikmatan pada perayaan ibadah. Pada saat peneliti mengikuti tata ibadah umat Hindu, peneliti meyaksikan secara langsung nyanyian nyanyian yang dilantunkan dalam perayaan ibadah atau sembhayang yang dipimpin secara bergiliran dari umat Hindu.

Berdasarkan hasil wawancara dengan informan yang bernama Shindu bahwasannya:

"Dalam bernyanyi lagu lagu pujian, yang memimpin nyanyian bebas orangnya tidak harus orang orang tertentu. Siapapun yang memimpin nyanyian ya semua umat ikut bernyanyi. Tapi, setiap nyanyian memiliki bagian tertentu untuk dewa-dewa tertentu misalnya nyanyian AUM untuk menyembah dewa Ganesha".

Berdasarkan hasil wawancara diketahui bahwasannya nyanyian dapat 
dipimpin oleh siapa saja baik dari anakanak serta orang dewasa. Salah satu nyanyian yang biasa dilantunkan oleh umat Hindu terhadap dewa Ganesha dalam perayaan ibadah yaitu nyanyian AUM dibaca OM sebagai bukti kecintaan terhadap dewa Ganesha. Nyanyian AUM merupakan suatu jalan yang digunakan untuk mengucapkan isi hati umat Hindu atas segala karunia dan rahmat Tuhan terhadap seluruh umat. Sewaktu peneliti mengikuti ibadah di kuil Shri Mariamman, peneliti menyaksikan pemimpin nyanyian adalah seorang anak kecil lalu selanjutnya dipimpin oleh orang dewasa. Pada tata perayaan ibadah umat Hindu nyanyian pujian dinyayikan dengan dua tempo yaitu tempo cepat dan tempo yang lambat.

Informan peneliti Pak Akash (laki laki 43 tahun) menyatakan bahwasannya:

"Pada nyanyian Hindu terbagi menjadi 2 tempo, lagu dalam nyanyian Hindu diulang-ulang. Pada nyanyian pertama dinyanyikan dengan tempo yang lambat sedangkan pada pengulangannya dinyanyikan dengan tempo yang cepat".

Berdasarkan hasil wawancara peneliti mendapatkan informasi bahwasannya tempo dalam menyanyikan lagu terbagi menjadi tempo cepat dan tempo yang lambat. Biasanya tempo nyanyian yang lambat dinyanyikan pada saat lagu pujian diulangi. Pada saat bernyanyi pemimpin menyanyikan dahulu lagu yang ingin dinyanyikan lalu diikuti oleh umat Hindu lain setelahnya.

Musik merupakan sarana yang menjadikan umat Hindu lebih dekat dengan Sang Yhang Whidi yaitu Tuhan pencipta alam semesta. Musik digunakan untuk mengiringi nyanyian dalam sembhayang sebagai bentuk pemujaan terhadap dewadewa. Pada saat melakukan observasi dan mengikuti perayaan ibadah, peneliti menyaksikan musik yang dilantunkan umat Hindu sebagai sarana pemujaan terhadap dewa-dewa dan Tuhan sangatlah teduh dan menyejukkan. Dalam perayaan ibadah satu dewa tertentu bisa dinyanyikan dengan dua atau tiga lagu yang diringi dengan alat musik sebagai penambah kesucian dari lagu lagu suci. Peran musik dalam perayaan ibadah umat Hindu di kuil shri mariamman yaitu sebagai pengiring dan penyampaian doa-doa terhadap Tuhan Sang Yhang Whidi dan dewa-dewa.

Berdasarkan penelitian yang dilakukan, peneliti menguraikan fungsi musik pada pelaksaan ibadah berdasarkan pendapat Alan P. Merriam sebagai berikut: (1) fungsi musik pengungkapan emosional, artinya musik dalam ibadah agama Hindu 
di Shri Mariamman sebagai media dari ungkapan hati yang berdoa dan memuji Tuhan. (2) Fungsi penghayatan estetis, artinya musik merupakan suatu karya seni yang menghasilkan keindahan dan menghasilkan khusyu atau dorongan hati yang fokus dan menghayati dalam beribadah. Sebagaimana dalam urutan tempo musik dalam peribadahan itu sendiri, pada saat tempo yang tinggi orang-orang yang beribadah semakin menghayati sesuai dengan alunan tempo musik itu sendiri. (3) fungsi hiburan, artinya Bhajan dapat diputarkan sebagai lagu-lagu rohani sehari-hari. (4) Fungsi Komunikasi, yang berarti musik dapat menjadi penghubung atau sarana penyampai informasi rohani dengan Tuhan. (5) Fungsi Perlambangan, Bhajan atau nyanyian peribadahan tersebut adalah khas bagi agama Hindu di Shri Mariamman. (6) Fungsi Reaksi Jasmani, pada saat peribadahan tempo musik memberikan reaksi gerak dan penghayatan yang berbeda-beda. (7) Fungsi yang Berkaitan dengan Norma, artinya Bhajan di sini dapat menjadi media penyampaian nilai-nilai dan norma-norma. (8) Fungsi Kesinambungan Budaya, Bhajan merupakan doa-doa dan pujian kepada para dewa yang diiringi musik dari Tabla atau sepasang dram tangan yang merupakan budaya India. (9) Fungsi Pengitegrasian Masyarakat, artinya musik merupakan media peribadahan yang membuat masyarakat pemeluk agama Hindu menjadi bersatu dan berdoa bersama-sama.

\section{Makna Musik Pada Pelaksanaan Ibadah}

Musik dalam pelaksanaan ibadah umat Hindhu, tidak bisa dipisahkan dengan tindakan penghormatan kepada hyang, yang diartikan dengan Sanghyang Widhi, atau lebih dikenaldengan istilah sembahyang. Dengan demikian, sembahyang berarti menghamba atau menghormat kehadapan Sanghyang Widhi untuk memohon kesucian diri.

Di dalam ajaran agama Hindu, sembahyang adalah wujud nyata kegiatan beragama dengan tujuan untuk mengagungkan kemahakuasaan Tuhan. Dan dalam melakukan sembahyang umat Hindu menggunakan media berupa saranasarana seperti sesajen, ucapan-ucapan suci (doa dan mantra), sikap diri, dan sikap batin.

Pada saat sembahyang, seseorang dengan khusus meluangkan waktu, mengatur diri, mempersiapkan segala perlengkapan sembahyang dengan perasaan yang tulus ikhlas tanpa 
mengikatkan diri pada hasilnya. Adapun maksud dan tujuan dari sembahyang adalah untuk: 1) Mohon kesucian jiwa Atma oleh sinar suci Ida Sanghyang Widhi untuk melenyapkan awidya (kegelapan batin), melenyapkan adharma (perbuatan tidak baik) serta peleburan dosa. 2) Untuk mengagungkan kemahakuasaan Ida Sanghyang Widhi, agar dapat menumbuhkan sikap tenang dan kreatif, tahan uji (tidak cepat putus asa) dan jujur. 3) Untuk memohon keselamatan, permohonan panjang umur, hormat, mengakui kelemahan dan keterbatasan. 4) Sebagai suatu usaha membalas hutang kepada Ida Sanghyang Widhi dan sebagai ungkapan permohonan maaf lahir dan batin atas dosa yang dibuat.

Keempa tujuan di atas, kemudian dalam ibadah mingguan, musik menjadi salah satu bagian utama dalam peribadahan umat Hindu di Kuil Shri Mariamman. Musik dijadikan sebagai pengiring doa-doa dan bentuk pemujaan umat Hindu yang dituangkan dalam bentuk nyanyian. Nyanyian digunakan sebagai bentuk penyampaian pemujaan bagi umat Hindu terhadap dewa-dewa serta Tuhan Sang Yhang Whidi sebagai pencipta alam semesta. Salah satu nyanyian yang dilantunkan umat Hindu dalam sembhayang sebagai bentuk penghormatan dan ucapan terimakasih atas karunia yaitu nyanyian AUM yang dibaca OM. AUM merupakan nyanyian umat Hindu yang ditujukan untuk menyembah dan memuja dewa khususnya dewa Ganesha yang merupakan salah satu dewa terkenal pada agama Hindu. AUM mempunyai nada nada khusus yang berirama dengan tempo tertentu. AUM dinyanyikan oleh umat Hindu bukan hanya pada saat sembhayang saja tetapi juga di nyanyikan sebagai bentuk pemberian salam dan rasa hormat terhadap Tuhan. AUM merupakan mantra doa berbentuk nyanyian umat Hindu yang di iringi dengan irama musik dengan bantuan alat musik seperti gendang dan tamborin.

Berdasarkan hasil wawancara dengan informan yang bernama Pak Sakha (45 tahun) bahwasannya :

"Musik dalam perayaan ibadah di kuil Shri Mariamman mengandung makna semangat dalam pemujaan serta pengabdian kepada Tuhan melalui dewadewa. Dengan adanya ïringan musik dalam nyanyian rohani umat Hindu menyatakan bahwa Tuhan telah memperkaya segala pendekatan bhakti umat Hindu dengan perantaraan lantunan 
musik yang indah. Musik menambah kesucian dalam ibadah ".

Berdasarkan hasil wawancara diketahui bahwasannya musik merupakan sebagai perantara jalan untuk kebaikan dan penunjuk jalan atas doa doa umat Hindu. Musik merupakan sarana umat Hindu dalam menunjukkan kecintaannya kepada Tuhan melalui lantunan nyanyian yang indah.

Nyanyian merupakan pelengkap dalam ibadah yang dapat menjadikan kata kata doa menjadi lebih hidup dan lebih tulus. Makna musik dalam peribadatan atau sembhayang menjadikan suasana lebih sakral dan suci. Nyanyian yang diiringi dengan musik menandakan pemujaan yang tulus dan sungguh sungguh dari umat Hindu. Umat Hindu di Kuil Shri Mariamman menggunakan nyanyian yang diringi dengan musik sebagai penambah semangat dalam memuja mensyukuri hikmat Tuhan. Dalam penelitian kami melihat komponen-komponen dalam ibadah di Kuil Shri Mariamman tersebut bahwa setiap komponen mempunyai arti dan makna yang salah satunya adalah musik. Dalam agama Hindu musik merupakan bagian dari simbol peribadatan yang digunakan sebagai penyampaian doa dan rasa syukur umat Hindu kepada Sang
Yhang Whidi. Musik dijadikan sebagai bentuk pengiringan dari nyanyian yang disebut dengan mantra sebagai doa-doa pemujaan. Salah satu nyanyian yang diiringi dengan musik adalah nyanyian AUM yang ditujukan kepada dewa Ganesha yang memiliki makna ketulusan dan rasa hormat.

Dalam kehidupan umat Hindu, musik adalah sebagai sarana untuk mengungkapkan emosi baik bagi yang mengucapkan maupun yang mendengar melalui lirik maupun melodi yang dimainkan atau diucapkan. Musik dan nyanyian juga berfungsi sebagai media penyampai komunikasi antara Sang Hyang Widhi Wasa dengan Bhakta yang mengucapkannya, di sisi lain, juga tak terlepas sebagai penyambung kebudayaan yang selalu dilaksanakan pada saat dilaksanakannya peribadatan.

\section{SIMPULAN}

Fungsi musik dalam ibadah agama Hindu di kuil Shri Mariamman adalah media dari ungkapan hati yang berdoa dan memuji Tuhan, menghasilkan keindahan dan kekhusyuan, penghubung atau sarana penyampai informasi rohani dengan Tuhan; memberikan reaksi gerak dan penghayatan yang berbeda-beda; media penyampaian 
nilai-nilai dan norma-norma; media Sang Hyang Whidi. Musik dijadikan peribadahan yang membuat masyarakat sebagai bentuk pengiringan dari nyanyian pemeluk agama Hindu menjadi bersatu dan yang disebut dengan mantra merupakan berdoa bersama-sama. doa-doa pemujaan yang tulus, sungguh-

Peran musik dalam perayaan ibadah sungguh, penambah semangat, umat Hindu yaitu sebagai sarana untuk penyampaian doa dan rasa syukur umat menambah kesucian dan kesakralan dalam Hindu kepada Sang Yhang Whidi.

beribadah, pengantar doa terhadap Tuhan

dan sebagai tanda kecintaan terhadap

\section{DAFTAR PUSTAKA}

Basrowi \& Suwandi. (2008). Memahami Penelitian Kualitatif. Jakarta: Rineka Cipta.

Batubara, Sandro. (2012). Studi Analisis Melodi, Fungsi Dan Makna Teks Mantra Dalam Konteks Upacara Mandalabhisekam Pada Masyarakat Hindu Tamil Di Kuil Shri Balaji Venkateshwara Koil Medan. Medan: USU.

Bungin, Burhan. (2007). Metodologi Penelitian Kualitatif. jakarta: Rajagrafindo Persada.

Cudamani, 1980. Pengantar Agama Hindu untuk Perguruan Tinggi. Jakarta: Yayasan Dharma

Geertz, Clifford. (1973). The Interpretation of Culture. New York: Basic Books.

Kamal, Ahmad. (2011). Upacara Mappanretasi Studi Realitas Keberagaman Warga Nelayan Bugis Pagatan Kalimantan Selatan. Surabaya: UIN Sunan Ampel Surabaya.

Koentjaraningrat. (1990). Pengantar Antropologi. Jakarta: PT. Rineka Cipta.

Kumar, S. (2009). Komunitas Tamil di Kota Medan (Suatu Etnografi Mengenai Etnik Tamil di Kelurahan Madras Huu, Kecamatan Medan Polonia). Medan: USU.

Lagu Bhajan, (2015)

Lubis, Riri Tegar, (2015), Analisis Nyanyian Bhajan Pada Sekte Sai Baba Di Medan, Skripsi Universitas Sumatera Utara.

Mirriam, Alan. P. (1964). The Anthropology of Musicq. Nortwestern Univercity. Moleong, Lexy. J. (2000). Metode Penelititan Kualitatif. Bandung: Remaja Rosdakarya. 
Murtana, I. Nyoman. (2011). Afiliasi Ritus Agama dan Seni Ritual Hindu Membangun Kesatuan Kosmis . MUDRA, 61-69.

Nazir. (1988). Metode Penelitian. Jakarta : CV Alfabeta.

Pasaribu, Herlina. Maysarah, (2018). Analisis Tekstual dan Musikal Bhajan pada Masyarakat Hindu Tamil di Kuil Shri Mariamman Medan, Skripsi Universitas Sumatera Utara.

Sarathy, Jhonny Edwin S., 1995. Pirartenei pada Aktifitas Religius Masyarakat Tamil di Shri Mariamman Kuil Medan: Kajian Struktur Musik dan Teks. Medan: Fakultas Sastra USU, Skripsi Sarjana Etnomusikologi.

Sinar, Lukman. (2008). Orang India di Sumatera Utara (The Indians in North Sumatera). Medan: Forkala.

Soedarsono. (1999). Seni Pertunjukan dan Pariwisata. Yogyakarta: BP ISI Yogyakarta.

Sugiyono. (2011). Penelitian Kualitatif dan Kuantitatif dan R \& D. Bandung: CV Alfabeta.

Theresia, Friskila. (2015). Bentuk Penyajian Nyanyian Bhajan dalam upacara Nawarati pada Masyarakat Hindu Tamil di Shri Mariamman Kuil Medan. Medan: Universitas Negeri Medan.

Van Hove, (1990), Ensiklopedia Indonesia.l, Jakarta: Ikhtisar Baru

Wiflihani, (2016), Fungsi Seni Musik dalam Kehidupan Manusia, Anthropos: Jurnal Antropologi Sosial dan Budaya (Journal of Social and Cultural Anthropology), 2 (1) (2016): 101-107.

Wiflihani., Widiastuti, Uyuni., Sembiring, Adina Sastra. (2018). Pengembangan Musikalitas Melalui Bunyi-Bunyi Alam pada Mahasiswa Program Studi Pendidikan Musik Universitas Negeri Medan. Gondang: Jurnal Seni dan Budaya, 2 (1): 20-27.

http://file.upi.edu/Direktori/FPIS M K D U/196011241988031 EDI SURESMAN/lbadah A spek Ritual Umat Islam.pdf diakses pada hari Minggu, 2 Desember 2019, pukul 10.00 WIB.

http://tikadenuvi.blogspot.com/2013/03/sejarah-fungsi-kuil-shri-mariamman-di.html?m=1 diakses pada hari Senin, 2 Desember 2019, pukul 10.12 WIB.

http://www/mantraHindu.com/sejarah-lengkap-agama-Hindu/ diakses pada hari Senin, 2 Desember 2019, pukul 10.30 WIB.

https://id.m.wikipedia.org/wiki/Kuil Shri Mariamman 
https://www.google.com/amp/sosiologis.com/metode-penelitian-deskriptif/amp?espv=1

https://idtesis.com/metode-deskriptif/

http://milmanyusdi.blogspot.com/2009/11/metodologi-penelitian-bab-iii.html?m=1

http://sosiologis.com/instrumen-penelitian/amp 